\title{
Construction Enterprises Innovating Activities on the Basis of Industry 4.0 and "Deep" Digital Transformations
}

\author{
Nataliia Kraus $\mathbb{D}$, Olena Zerniuk $\mathbb{D}$, and Alina Chaikina $\mathbb{D}$
}

\begin{abstract}
Characteristic features of the research and innovation impact on construction enterprises digitization were investigated and generalized in the article. Creation of digital industrial platforms of construction industry in different countries of the world and their adaptation to market realities was analyzed. It was established by authors that in order to transform construction enterprises management system in Ukraine, and the implementation of industry digitalization must be primarily aimed at developing mechanisms for adapting country's economic system to European space and realizing projects that require collective efforts with involvement of public and private stakeholders on regional and national levels. It was argued that the main factors slowing down dynamics of construction complex development in Poltava region include: significant currency fluctuations, liquidity crisis of banking institutions, and reduction of the population solvent demand. Introduction of new forms of relationships between enterprises, government, public authorities, universities, in particular, by forming a cluster on the basis of innovative hub makes possible ensuring exit of construction complex from economic crisis and perspective development of construction complex in Poltava region. It was confirmed by researches that there should be effective interaction in the "technical education-business of the construction sphere-innovative activity" chain and professional consultations by establishing a clear organization of "technical universities - scientific researchesproduction-construction" should be provided. Measures to combine potential of research, innovative development directly with industry and practical construction were substantiated and revealed. Authors developed a real model of construction cluster in Poltava region created on the basis of an innovative hub. It was also concluded that the main advantage of proposed clustering approach on the basis of
\end{abstract}

\footnotetext{
N. Kraus

Borys Grinchenko Kyiv University, Kiev, Ukraine

e-mail: k2205n@ukr.net

O. Zerniuk

Poltava National Technical Yuri Kondratyuk University, Poltava, Ukraine

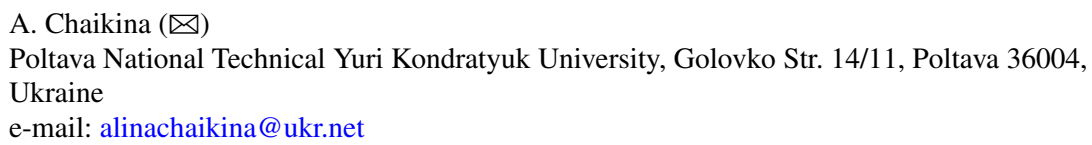


innovative hub is that due to such development of cluster systems, higher school can effectively integrate results of higher, academic and sectoral science of Ukraine, as well as advanced results of the world community science in development and implementation of innovative projects in the field of construction.

Keywords Innovation - Construction sector · Construction enterprises • Innovation hub $\cdot$ Industry $4.0 \cdot$ Digital transformation

\section{Introduction}

In Ukraine, the innovation activity of industrial enterprises remains at a very low level for many years, thus in 2016, only $18.9 \%$ of enterprises were engaged in innovative activity. In 2015, only 723 enterprises were innovating: 400 of which implemented new technological processes and 570 realized innovative products. Since 2010, amount of sold innovative products has decreased by almost $32 \%$, from 33697.6 to 23050.1 million UAH, and amount of innovative products supplied for export was only $21 \%$. Total innovation expenditures in the industry during this period increased by almost $72 \%$ from 8045.5 million UAH to $13,813.7$ million UAH, while expenditures of foreign countries decreased from 2411.4 million UAH to 58.6 million UAH or $97 \%$. The main source of innovation financing costs is institutions and enterprises own funds, which account for $85 \%$ of the total funding. State has practically shied away from financial impact on these processes. Domestic industrial complex is based on industries focused on low-tech production and export of raw materials, and factors that ensure the competitiveness of the national economy: availability of labor, natural resources, and capital.

Deterioration of technological structure of production testifies consolidation of export-raw model of economic development in Ukraine. Thus, if in 2002 share of high-tech and medium-tech industries accounted for $22.2 \%$ and $43.1 \%$, in 2017 it decreased to $17 \%$ and $41.7 \%$, share of low-tech industries increased from $34.7 \%$ to $41.3 \%$ instead. In 2017, Cabinet of Ministers of Ukraine established the National Committee for Industrial Development, which should lay the foundations for institutional renewal of domestic production. The issue is about formation of value chains, which entails changing approaches to innovation and investment, as well as moving closer to private business. The main task is development of domestic production, creation of new jobs and new added value, rather than increasing imports [1, p. 21]. 


\subsection{An Analysis of Recent Research and Publications and Selection of Previously Unsolved Parts of the General Problem}

Construction enterprises innovation activity on the basis of Industry 4.0 and "deep" digital transformations were investigated by such famous scientists and inventors as W. Isaacson, S. Brand, J. Wells, E. Williams, B. Gates, G. Jacobs, B. Elbrecht, D. Engelbart, J. von Neumann, E. Reinert, S. Huntington, and J. Shapiro. Economists from Ukraine are also actively involved in analyzing positive and negative consequences that Industry 4.0 brings to economy and production, revealing product content and technological innovations generated by the Fourth Industrial Revolution and determining emergence of "Industry X.0" in the world. Among them are V. Heitz, V. Galasyuk, A. Hrytsenko, S. Kubiv, A. Medvedev, D. Oliynyk, R. Pustovit, and O. Yaremenko. But, at the same time, there is a number of actual issues such as revealing the content of risks that construction companies face as they grow; development of innovative hub model in the Poltava region construction cluster, remains still relevant and needs to be studied.

\subsection{Purpose of the Article}

Purpose of the article is to study features of creating digital industrial platforms of construction industry in different countries of the world, presentation of preventive blitz-diagnosis of problems and risks of construction enterprises at the stage of their growth. As well as to find out options for correlating the life stages of a "construction company —innovation market — new product" with development of preliminary recommendations for all options, analysis of the innovative hub developed model for construction cluster in the Poltava region, substantiation, and disclosure of measures to combine potential of scientific research, innovative development directly with industry and practical construction.

\section{Main Material of Research Work with Justification of the Obtained Scientific Results}

Modern innovative technologies such as: cloud technologies, modern ways of collecting and analyzing big data, crowdsourcing, cryptocurrency, blockchain technologies, unmanned vehicles, etc., are radically changing entire sectors of the economy. Based on these technologies, digital revolution becomes the Fourth Industrial Revolution (Industry 4.0), essence of which is mass introduction of cyber-physical systems into production, which blurs boundaries between physical, digital, and biological spheres, and emergence of an entirely new type of industrial production based on 
processing of a large array of data to achieve complete automation of production and implementation of the latest scientific and technological advances in technological processes. It is anticipated that these cyber-physical systems will integrate into one self-regulating network, connect to each other in real-time, and promote radically new ways of interacting in the value-adding process [2, p. 7].

In Ukraine, the development of construction enterprises is based on various investment funds. For these reasons, there is a need to develop a complete system of support for innovative projects, which should include the creation of innovation-venture funds and hubs of construction. For these purposes, it is proposed to bring the number of small construction enterprises in Ukraine up to $90 \%$ of their total. However, it should be noted that it is difficult for Ukrainian construction companies to compete with foreign enterprises that promote modern innovative projects, because they use material and technical base that they have inherited since the Soviet era.

The activity of a construction enterprise is the equilibrium of two vectors: [owner, will, freedom, innovation] + [state, obligation, necessity, coercion, subjugation, dependence]. The complexity of analysis lies in the fact that essential factors of first and second groups condition each other [3, p. 63]. Preventive blitz-diagnosis of problems and risks of construction industry at the stage of their growth is presented in Table 1.

Creating digital industrial platforms for construction industry and adapting them to market realities are essential processes to ensure scale and coverage of national and regional initiatives to digitize construction industry and economic entities initiatives [2, p. 13]. Digitizing European Industry (DEI) seeks to bring together common interests on the Platform Economy and secure future global standards for connecting smart construction enterprises and involves investing in digital innovation opportunities based on information and communication technologies (ICT) standards and adaptation of workforce by training human capital to acquire necessary digital transformation skills [2, p. 14].

Innovation leads to a closer interdependence between the advancement of digital technologies and their use in different industries and requires creation of highly innovative digital sectors and renewal of digital innovation capacity of all industries. In this purpose, several national and regional initiatives have been launched to take advantage of the opportunities offered by digital innovation in Europe, including: Industrie 4.0 (DE), Smart Industry (NL), Catapults (UK), and Industrie du Futur (FR) [6]. For example, for Industrie 4.0 in Germany was created Reference Architectural Model Industrie 4.0 (RAMI 4.0) based on the Standard IEC62264 for integrating management systems in construction industry, which promotes an understanding of what standards are required to implement Industry 4.0. Standard IEC62264 details models of production operations objects and attributes, integration and management of production operations, messaging and business services and more. In addition, in Germany associations, ProSTEP and ViP have developed a directory of compatibility criteria for infrastructure, interfaces, standards, architectures, and more in the form of Product Lifecycle Management (PLM-Code for PLM Openness, CPO) [7].

Examples of national and regional programs that improve industrial production digitization, namely construction companies, are initiatives launched by different 
Table 1 Preventive blitz-diagnosis of problems and risks of construction enterprises at the stage of their growth (compiled by the authors on the basis of sources [4, p. 102]; [5, p. 425-446])

\begin{tabular}{|c|c|c|}
\hline $\begin{array}{l}\text { Possible options for the life } \\
\text { cycle ratio: "construction } \\
\text { enterprise (CE)—innovation } \\
\text { market (IM)—new products } \\
\text { (NP)" }\end{array}$ & $\begin{array}{l}\text { Preliminary diagnosis of } \\
\text { major problems and risks of } \\
\text { CE }\end{array}$ & Previous recommendations \\
\hline $\begin{array}{l}\text { 1. Growth CE-embryonic } \\
\text { state IM-technical idea for } \\
\text { NP creation }\end{array}$ & $\begin{array}{l}\text { Problem is related to the need } \\
\text { for rapid implementation of } \\
\text { the technical idea and NP } \\
\text { entering on IM. The most } \\
\text { significant risk is the } \\
\text { mismatch of the expected and } \\
\text { actual consumer response to } \\
\text { the NP }\end{array}$ & \multirow[t]{2}{*}{$\begin{array}{l}\text { Develop a rigorous timetable } \\
\text { for activities that provide a } \\
\text { fast and efficient transition } \\
\text { from a technical idea to a } \\
\text { serial NP release. Clearly } \\
\text { motivate managers to } \\
\text { implement the plan in terms } \\
\text { of time and quality }\end{array}$} \\
\hline $\begin{array}{l}\text { 2. CE Growth-IM } \\
\text { Crystallization-Technical } \\
\text { Idea of Creating NPs }\end{array}$ & $\begin{array}{l}\text { Problem is the same, but time } \\
\text { is limited. The main risks are } \\
\text { events that can slow down the } \\
\text { output process IM } \\
\text { (counterparties, internal } \\
\text { inconsistencies) }\end{array}$ & \\
\hline $\begin{array}{l}\text { 3. CE Growth-IM } \\
\text { Growth-Technical Idea of } \\
\text { Creating NPs }\end{array}$ & $\begin{array}{l}\text { Problem is the same, but the } \\
\text { time resource is almost } \\
\text { exhausted. The main risks are } \\
\text { the same }\end{array}$ & $\begin{array}{l}\text { Mobilize all resources for } \\
\text { organizing NP output } \\
\text { activities on IM }\end{array}$ \\
\hline $\begin{array}{l}\text { 4. CE Growth-IM } \\
\text { Saturation-Technical Idea of } \\
\text { Creating NPs }\end{array}$ & \multirow[t]{3}{*}{ Technical idea was "late" } & \multirow{3}{*}{$\begin{array}{l}\text { Use technical idea for a } \\
\text { second product that addresses } \\
\text { the needs of a more } \\
\text { promising IM (second market } \\
\text { niche) sector }\end{array}$} \\
\hline $\begin{array}{l}\text { 5. CE Growth-IM } \\
\text { maturity-Technical Idea of } \\
\text { Creating NPs }\end{array}$ & & \\
\hline $\begin{array}{l}\text { 6. CE Growth-IM } \\
\text { decline-Technical Idea of } \\
\text { Creating NPs }\end{array}$ & & \\
\hline $\begin{array}{l}\text { 7. CE Growth-Embryonic } \\
\text { state IM-NP development }\end{array}$ & $\begin{array}{l}\text { There are no visible } \\
\text { problems. There is a good } \\
\text { chance for a successful CE } \\
\text { development in the future. } \\
\text { The main risk is the mismatch } \\
\text { of expected and actual } \\
\text { consumer response to the NP }\end{array}$ & $\begin{array}{l}\text { Perform continuous IM status } \\
\text { analysis. Develop the } \\
\text { program for the fastest and } \\
\text { most effective product } \\
\text { promotion }\end{array}$ \\
\hline $\begin{array}{l}\text { 8. CE Growth-IM } \\
\text { Crystallization-NP } \\
\text { development }\end{array}$ & $\begin{array}{l}\text { There are no visible } \\
\text { problems. But the time } \\
\text { available for IM output is } \\
\text { limited. The main risk is the } \\
\text { same + events that can slow } \\
\text { down output on IM } \\
\text { (counterparties, internal } \\
\text { mismatches) }\end{array}$ & $\begin{array}{l}\text { Develop a timetable for } \\
\text { activities that enable rapid } \\
\text { and efficient transition from } \\
\text { product development to serial } \\
\text { production. Clearly motivate } \\
\text { managers to implement the } \\
\text { plan }\end{array}$ \\
\hline
\end{tabular}


Table 1 (continued)

\begin{tabular}{|c|c|c|}
\hline $\begin{array}{l}\text { Possible options for the life } \\
\text { cycle ratio: "construction } \\
\text { enterprise (CE)—innovation } \\
\text { market (IM)—new products } \\
\text { (NP)" }\end{array}$ & $\begin{array}{l}\text { Preliminary diagnosis of } \\
\text { major problems and risks of } \\
\mathrm{CE}\end{array}$ & Previous recommendations \\
\hline $\begin{array}{l}\text { 9. CE Growth-IM } \\
\text { Growth-NP development }\end{array}$ & $\begin{array}{l}\text { The main problem is the } \\
\text { limited time resource for NP } \\
\text { output to EM. The main risks } \\
\text { are the same }\end{array}$ & $\begin{array}{l}\text { Mobilize all resources to } \\
\text { accelerate NP exit measures } \\
\text { on IM }\end{array}$ \\
\hline $\begin{array}{l}\text { 10. CE Growth-IM } \\
\text { Saturation-NP development }\end{array}$ & $\begin{array}{l}\text { Development is "late." It is } \\
\text { obvious that there are } \\
\text { problems in management and } \\
\text { marketing }\end{array}$ & $\begin{array}{l}\text { Use development for a } \\
\text { second NP that is more } \\
\text { demand-oriented }\end{array}$ \\
\hline $\begin{array}{l}\text { 11. CE Growth-IM } \\
\text { maturity-NP development }\end{array}$ & \multirow{2}{*}{$\begin{array}{l}\text { Organization of the main } \\
\text { processes is "limping." The } \\
\text { main risk is deterioration of } \\
\text { financial condition }\end{array}$} & \multirow[t]{2}{*}{$\begin{array}{l}\text { Reorganize the main } \\
\text { processes }\end{array}$} \\
\hline $\begin{array}{l}\text { 12. CE Growth-IM } \\
\text { decline-NP development }\end{array}$ & & \\
\hline $\begin{array}{l}\text { 13. CE Growth-Embryonic } \\
\text { state IM-NP output to IM }\end{array}$ & \multirow{2}{*}{$\begin{array}{l}\text { Has a chance for successful } \\
\text { development of CE in the } \\
\text { future. The main risk is } \\
\text { mismatch between the } \\
\text { expected and actual consumer } \\
\text { response to the NP }\end{array}$} & \multirow{2}{*}{$\begin{array}{l}\text { Continuously monitor } \\
\text { consumer response to NP and } \\
\text { IM status. Develop the } \\
\text { program for fastest and most } \\
\text { effective promotion of NP }\end{array}$} \\
\hline $\begin{array}{l}\text { 14. CE Growth-IM } \\
\text { Crystallization-NP output } \\
\text { to IM }\end{array}$ & & \\
\hline $\begin{array}{l}\text { 15. CE Growth-IM } \\
\text { Growth-NP output to IM }\end{array}$ & $\begin{array}{l}\text { Unbeatable/wonderful! There } \\
\text { are no problems. An internal } \\
\text { nature is risks of paramount } \\
\text { importance: will the company } \\
\text { "drive" such rapid/rapid } \\
\text { growth? }\end{array}$ & \multirow[t]{2}{*}{$\begin{array}{l}\text { Analyze and refine basic } \\
\text { processes. Pay more attention } \\
\text { to discipline, responsibilities } \\
\text { and powers }\end{array}$} \\
\hline $\begin{array}{l}\text { 16. CE Growth-IM } \\
\text { Saturation-NP output to IM }\end{array}$ & $\begin{array}{l}\text { Exit to IM NP "with some } \\
\text { delay." Underestimation of } \\
\text { management. Difficulties } \\
\text { with CE financial condition }\end{array}$ & \\
\hline $\begin{array}{l}\text { 17. CE Growth-IM } \\
\text { maturity-NP output to IM }\end{array}$ & $\begin{array}{l}\text { Same, but financial problems } \\
\text { can be more serious }\end{array}$ & $\begin{array}{l}\text { Same }+ \text { modify NP for more } \\
\text { promising IM (other market } \\
\text { niche) sector }\end{array}$ \\
\hline $\begin{array}{l}\text { 18. CE Growth-IM } \\
\text { decline-NP output to IM }\end{array}$ & $\begin{array}{l}\text { Exit NP on IM came too late. } \\
\text { Obvious problems in } \\
\text { management and marketing. } \\
\text { Financial losses can be } \\
\text { critical for CE }\end{array}$ & $\begin{array}{l}\text { Reorganize management } \\
\text { system and major CE } \\
\text { processes. Modify NP for } \\
\text { more promising sector of IM } \\
\text { (other market niche) }\end{array}$ \\
\hline $\begin{array}{l}\text { 19. CE Growth-IM } \\
\text { crystallization-growth in } \\
\text { sales of innovation }\end{array}$ & $\begin{array}{l}\text { Situation is quite promising } \\
\text { for CE. The main problem is } \\
\text { to maintain a position in the } \\
\text { emerging market. The main } \\
\text { risks are actions by } \\
\text { competitors }\end{array}$ & $\begin{array}{l}\text { Constantly analyze the status } \\
\text { of IM, and especially actions } \\
\text { of competitors. Ensure that } \\
\text { CE (in organization of key } \\
\text { processes) is prepared for its } \\
\text { potential growth }\end{array}$ \\
\hline
\end{tabular}


Table 1 (continued)

\begin{tabular}{l|l|l}
\hline $\begin{array}{l}\text { Possible options for the life } \\
\text { cycle ratio: "construction } \\
\text { enterprise (CE)_innovation } \\
\text { market (IM)—new products } \\
\text { (NP)" }\end{array}$ & $\begin{array}{l}\text { Preliminary diagnosis of } \\
\text { major problems and risks of } \\
\text { CE }\end{array}$ & Previous recommendations \\
\hline $\begin{array}{l}\text { 20. CE Growth-IM } \\
\text { growth-NP sales growth }\end{array}$ & $\begin{array}{l}\text { Fantastic situation! The } \\
\text { problem is to save this } \\
\text { situation. Internal risks are } \\
\text { most clearly seen: in terms of } \\
\text { analyzing trends in the } \\
\text { development of IM, as well } \\
\text { as the organization of major } \\
\text { CE processes }\end{array}$ & $\begin{array}{l}\text { Constant IM analysis. Ensure } \\
\text { CE readiness to move to } \\
\text { another product line or to } \\
\text { another (niche) IM sector }\end{array}$ \\
\hline $\begin{array}{l}\text { 21. CE Growth-IM } \\
\text { Saturation-stable sale of NP }\end{array}$ & $\begin{array}{l}\text { There are no obvious } \\
\text { problems. The main risk is } \\
\text { the financial loss that can } \\
\text { occur if CE "hangs" on IM } \\
\text { with an "old" product }\end{array}$ & $\begin{array}{l}\text { Develop a production } \\
\text { upgrade program: move to } \\
\text { another product range or to } \\
\text { different sectors (niches) of } \\
\text { IM }\end{array}$ \\
\hline $\begin{array}{l}\text { 22. CE Growth-IM } \\
\text { maturity-NP sales stability }\end{array}$ & $\begin{array}{l}\text { Problem is in the limited time } \\
\text { available for "production } \\
\text { upgrades." The most } \\
\text { important are marketing risks } \\
\text { as well as risks related to } \\
\text { reorganization of internal } \\
\text { processes }\end{array}$ & $\begin{array}{l}\text { Implement the production } \\
\text { upgrade program }\end{array}$ \\
\hline
\end{tabular}

European countries: in Sweden, it is "Produktion 2030"; in Spain-“Industry 4.0"; in France-Industrial Alliance "Industrie du Futur"; in Italy-Italy's National Industrial Plan and others. China's manufacturing companies also show interest in digitizing construction companies, but take a different approach, relying more on direct investments in European companies, such as Krauss-Maffei, Stoll, Manz Group, Kuka, which are important to them. China's level of investment in relevant technologies exceeds the EU level. Common programs in China are "Made in China 2025", which is considered as Chinese equivalent of Industry 4.0, and Internet Plus (IP).

In order to transform construction enterprise management systems in Ukraine, implementation and realization of industry digitization should be primarily aimed at developing mechanisms for adapting country's economic system to European space and for Projects of Common Interest (PCIs) implementation which is a matter of common interest and require collective efforts involving both public and private stakeholders at regional and national levels. Due to this, international practice has established a framework for identification, planning, and implementation of PCIs based on the provision of a single coherent regulatory framework [2, p. 15].

Aspects that can determine success of an innovative "young" construction company in Ukraine are the following: speed of development, which corresponds to the speed of development of construction market (if the company has an idea, it is necessary to act because there is no time for its "bearing"- it will be necessary to 
supplement and "grind" it during implementation); ability for partnership and synergy (no construction company in innovation economy will "survive" alone-only forming alliances, hubs, and partnerships is inevitable); ability for innovation and continuous innovation development; cultivation of talents; globality in innovative thinking (projects should target both local construction markets as well as to the world).

Within enterprise of construction industry, functions that performed by ideology at institutional level nowadays move to organizational culture. In any institute, enterprise, trade union or political party there is a common cognitive component-organizational knowledge [8, p. 195]. Organizational culture of a construction company materializes in rules and traditions on which relationship between "principal" and "agent" are based. Interpretive function of organizational culture of construction enterprise is based on the use it by "agents" to evaluate validity of "principal" decisions in case of any unforeseen circumstances. In our case, this could be a risk during realization an innovative project by a construction company.

Organizational cultural of a construction company, in our opinion, should be formed taking into account level of innovative behavior of its employees. By innovative behavior, we mean a set of actions while creating innovations and reaction to conditions of innovative construction activity. Complexes of organizational routines create an organizational innovation culture of entrepreneurial structure of construction industry.

Construction companies are a set of principal-agent relationships as a mechanism of limited divergence between economic entities and an internal organization, taking into account decisive role of transactional construction costs. Hence, it can be argued that intercompany relations is a contract whereby one or more persons ("principals") hire other persons ("agents") to carry out innovative construction projects or to transact based on delegated authority and principal decisions [9, p. 14-15], on innovative activity in the field of construction [10].

Effective interaction in the chain of "technical education-construction business-innovation activity" should be worked out and professional consultations should be provided by establishing a clear organization "technical universities - scientific research-production-construction." It should continue to follow the concept of "innovation triangle," which is based on rapid and successful implementation of breakthrough innovations in the industry and requires cooperation of three different subjects: consumer, developer, and inventor. The main purpose of such collaborations is to activate innovative activities of technical university graduates. Universities will train young professionals and research staff, capable of initiating and implementing innovative projects, as well as releasing independent entrepreneurs of high-tech construction businesses. Working on real innovative projects will allow students to acquire new knowledge and transfer technology in the course of communication with the staff of construction enterprises. The transfer will also take place through migration of scientists between construction companies and technical university, which will allow them to acquire necessary knowledge without expense of intellectual property rights. 
In the context of the study, we give an example of an innovative construction cluster within the Poltava region as a spatially localized association of participants in the investment-building process, innovative enterprises of building materials and other related industries, research institutes, universities, banking institutions, public authorities, local authorities in order to increase level of construction products competitiveness and increase economy of the region as a whole.

The main factors slowing down dynamics of construction complex development in the Poltava region include: significant currency fluctuations, liquidity crisis of banking institutions, and reduction of solvent demand of population. Ensuring the building complex recover from the economic crisis and prospective development is possible with introduction of new forms of relationships between enterprises of the industry, government, public, universities, in particular, by forming a cluster on the basis of innovative hub. The real model of a construction cluster in the Poltava region created on the basis of an innovative hub is presented in Fig. 1.

As can be seen from Fig. 1 that to construction cluster of the Poltava region should be included all participants of investment and construction complex.

Among investment and construction companies that we believe should join this cluster firstly are large construction and assembly organizations that have experience, reputation, and consistently high profits.

We consider including to the cluster of 3-4 investment and construction companies focused on implementation of individual investment projects to be effective. It should be noted that this innovative hub of the construction cluster is a node to support high intensity of innovation, through which all logistics of innovative development of the region goes. This type innovative hub will allow to form regional innovation markets, to ensure a dominant presence in them, to organize capital inflows (primarily venture capital), to set "rules of the game," to define norms of relations between the entities, and to form a creative and innovation-oriented human resources reserve. The innovation hub will facilitate rapid and high-quality integrated "processing" of innovations (as ideas) into innovative products that will be successfully implemented in the high-tech markets of the region.

The main advantage of our innovative hub-based clustering approach is that due to this cluster systems development, higher education can effectively integrate results of higher, academic and sectoral science of Ukraine, as well as advanced results of science of the world community in development and implementation of innovative projects.

Thus, the formation of an institutional environment based on clustering provides a powerful impetus for building an effective innovation economy in the context of comprehensive modernization. Today's the stage of modernization should foresee, first and foremost, a large-scale upgrade of production under influence of formation of advanced VI technological structure.

Due to instability, the extreme variability of the basic elements of Ukrainian society and presence of residual phenomena of previous development, Government of the country is facing fundamentally new tasks that it must solve in the course of institutional changes. 


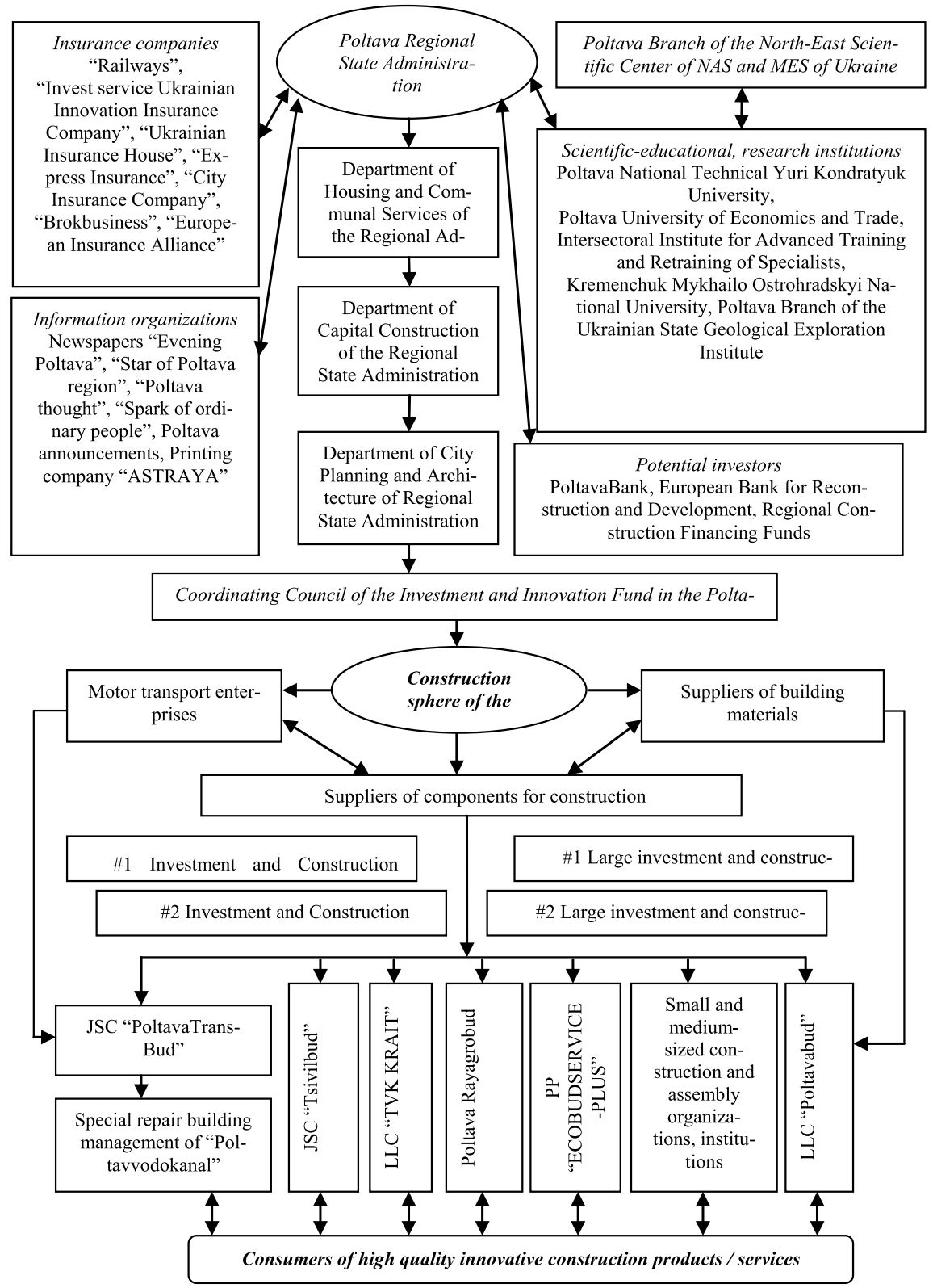

Fig. 1 Model of construction cluster innovation hub in the Poltava region (development by authors) 
We believe that the creation of clusters based on innovative hubs is one of the key factors of the country economic growth, which provides a comprehensive system of support for economic and technological interdependence. Therefore, we propose to consider the interaction between participants of innovation process in innovation cluster as a basis for increasing competence, competitiveness and level of cooperation between firms and other institutes, institutions in the sphere of innovation.

From an institutional point of view, a necessary condition for construction an innovative type of national economy is conformity of the relations of innovation development main participants with principles of the triple helix. Verticalization of Ukrainian economy is a "stumbling block" for innovative development of construction sector. The "technical university-government—construction business" model contrasts with vertical mechanisms of managing innovative development of establishing and improving horizontal links between participants in innovation process of construction industry.

Institutions of consolidation, consistency, quality are the basic parameters of this model. To ensure right momentum, collegial bodies, industry alliances of innovators should be created, and systematically decentralized decision-making processes, turning them into joint initiatives.

We are convinced that today a number of measures need to be taken to combine potential of research and innovative development directly with industry and practical construction, including:

1. Define nature, legal forms, and scope of activities (including financing and revenue structure) of innovation support and construction business infrastructure (techno parks, business incubators, technology transfer structures, innovation hubs). It is needed to focus efforts on creating conditions for control of innovative and commercial activities and benefits for construction techno parks. The number of techno parks should be clearly limited (up to 5) and they should operate within control and incentive mechanism, which would prevent inappropriate use of benefits for innovative projects by other (non-innovative) economic operators.

2. On the basis of the leading national technical universities of Ukraine activity of university construction hubs as "platforms" for acceleration of ideas should be created/started. Technical universities that are characterized by efficient operation of innovative construction hubs should be given full financial autonomy to enable them to carry out certain financial transactions, bypassing in most cases lengthy and tedious procedures for applying to the Treasury of Ukraine. Allow technical universities engaged in innovative construction business to use funds provided as assistance, grants, gifts, sponsorship, without following public procurement procedures provided for by Ukrainian law.

3. Encourage technical universities and research institutes to innovation construction activities, allowing them not to tax all the revenues from licensing and spinoff companies and directs them to modernization of universities' laboratories and equipment.

4. Determine the amount and procedure of paying for intellectual property to the creators. In case of acquisition of inventions rights and other objects of intellectual 
property right to public authorities, to introduce procedure of licensing and access to information about such objects.

5. Through government programs, promote involvement of scientists to work in construction industry. Provide joint funding for employment of such scientists in specific innovative construction projects. Establish a doctoral and postgraduate institute with joint funding from industry and state. State should stop practice of national publications domination in the course of scientific evaluation and move to an internationally recognized system of scientific research evaluation.

6. It is necessary to develop a new state program for forecasting scientific, technological, and innovation development in search of innovative breakthrough directions and ensuring competitiveness of the Ukrainian economy in the field of construction. It is advisable to implement a "single window" principle during providing participants of industrial park such services as: approval of project documentation, approval of documents for maintenance in the territory of land plot, issuance specifications for reinforcement objects to the engineering networks and structures.

7. While ensuring development of industrial parks, more attention should be paid to application of public-private partnership principles and mechanisms for granting certain preferences as an example is deferred payment mechanism "Tax Increment Finance," harmonization of industrial park activities with the needs of technological modernization and sectoral priorities of innovative development.

\section{Conclusions}

Participants and leaders of developed countries at the 46th World Economic Forum in Davos, held in January 2016, emphasized beginning of the Fourth Industrial Revolution. It was noted at the Forum that this revolution would lead to elimination of barriers between machine and person and promote their integration, and consequently would cause dramatic technological changes in the world economy and way of people life. In order to avoid possible socio-economic, technological upheavals and institutional chaos that this revolution is carrying, it is already necessary to calculate today possible negative consequences and to consider additional problems and aspects that need to be addressed. In the context of innovative development of a knowledge-based society, it is necessary to avoid two "end points" on the innovation spectrum. First one is to support exclusively science and research in the construction industry. Second one is to focus on construction of large structures that house high-tech companies. 


\section{References}

1. Draft Parliamentary Hearing Recommendations on the theme: "National Innovation System: State and Legislative Support for Development". Homepage, http://ua-ekonomist.com/archive/ 2018/3/rekom.pdf, Accessed 18 Jan 2019.

2. Oliynyk, D. I. (2018). Innovative development of territorial communities in the conditions of the fourth technological revolution: priorities and prospects (analytical. report). Kiev: NISD.

3. Yaremenko, O. L., \& Pankratova, O. M. (2007). Institutions and economic freedom of economic entities. Economic Theory, 3, 63.

4. Medvedeva, A. M. (2011). Blitz-analysis of a growing company and risk management. Modernization Innovation Development, 3(7), 102-104.

5. Kraus, N. (2019). An innovative economy in the globalized world: an institutional basis for formation and a trajectory of development. Kiev: Agrarian Media Group.

6. Communication from the Commission to the European Parliament, the Council, the European Economic and Social Committee and the Committee of the Regions Digitising European Industry Reaping the full benefits of a Digital Single Market \{SWD (2016) 110 final\} Homepage, http://eurlex.europa.eu/legalcontent/EN/TXT/?uri=CELEX:52016DC0180, Accessed 15 Jan 2019.

7. Code of PLM openness homepage, https://www.techniatranscat.com/abouttechniatranscat/ abouttechniatranscat/codeofplmopenness, Accessed 14 Jan 2019.

8. Sapir, J. (1995). Culture economique, culture technologique, culture organisationnelle elements pour une interpretation de l'histoire economique russe et sovietique. Cahiers du Monde Russe, XXXVI(1-2), 195.

9. Pustovit, R. F. (2005). Institutional specificity of internal-firm relations "principal-agent" researches. Scientific works of DonNTU, 89-2, 14-15.

10. Varnaliy, Z., Onishchenko, S., \& Masliy, A. (2016). Threat prevention mechanisms of Ukraine's economic security. Economic Annals-XXI, 159(5-6), 20-24. 